\title{
Economics
}

2015; 4(6): 106-111

Published online October 31, 2015 (http://www.sciencepublishinggroup.com/j/eco)

doi: $10.11648 /$ j.eco.20150406.12

\section{Assessment of Banking Performance Using Capital Adequacy in Ethiopia}

\author{
Dakito Alemu ${ }^{1,2}$ \\ ${ }^{1}$ Department of Commerce and Management Studies, College of Arts and Commerce Andhra University, Andhra, India \\ ${ }^{2}$ Department of Accounting and Finance, School of Commerce, Addis Ababa University, Addis Ababa, Ethiopia
}

\section{Email address:}

dalemu22@gmail.com

\section{To cite this article:}

Dakito Alemu. Assessment of Banking Performance using Capital Adequacy in Ethiopia. Economics. Vol. 4, No. 6, 2015 , pp. $106-111$. doi: $10.11648 /$ j.eco.20150406.12

\begin{abstract}
The data used in this study were collected from financial reports of eight sample banks and National bank of Ethiopia (NBE) for the period of 2000-2013. The objectives of the study were to evaluate the financial performance of banking sector in the Ethiopia and also to see the relation between capital adequacy and bank's performance. In order to address these, both descriptive and econometric analyses were employed so as to assess the financial performance of the sector and the relationship between capital adequacy and bank performance. The descriptive analyses were made using CAMEL approach and central tendency measures. The descriptive data analysis shows that, as compared to other banks NIB's overall performance was good.In addition to the descriptive data analysis, the study also employed regression model, GLS, which is used to see whether capital adequacy which is measured by the amount of shareholders fund affect the bank performance which is measured by Return on asset (ROA). The finding shows that, shareholders' fund is the main factor that determines the performance of banking industry hence, the null hypothesis is rejected. Therefore, there exists positive relationship between capital adequacy and bank performance at $5 \%$ significant level, which is in line with theory.
\end{abstract}

Keywords: CAMEL, CAR, LA, GLS, ROA

\section{Introduction}

The growth and stability of the financial condition of a country depend on the soundness of its banking sector. The firmness of the banking system is an important concern for regulatory authorities, bank customer and stockholders. To prevent the financial crisis, the banking activity is heavily regulated all over the world. This involves controlling of bank risk-taking and ensuring compliance with set prudential regulation set by the central bank such as liquidity requirements, capital adequacy rules, and risk management tools. Financial institutions intermediate between the savers of funds and users of funds. It is hoped that the changes now occurring will enable financial institutions to serve their customers better, strengthen the institutions by broadening and diversifying their operations and promote competition among intermediaries.

The history of formal financial system in Ethiopia is attached to the establishment of Bank of Abyssinia just a century back. Bank of Abyssinia was established as the first bank in 1905 based on the agreement signed between the
Ethiopian government and the National Bank of Egypt, which was owned by the British. Its capital was 1 million shillings. According to the agreement, the bank was allowed to engage in commercial banking (selling share, accepting deposit and effecting payments in checks) and to issue currency notes. The agreement prevented the establishment of any other bank in Ethiopia, thus giving monopoly right to the bank of Abyssinia. Today there are opportunities to invest in financial institutions with policies encouraging private investors to invest in the banking, microfinance and insurance companies. Although the history of private commercial banks in the country is very short, the banks have managed to contribute their part in provision of banking services and sharing the monopolies enjoyed formerly by the state owned Commercial Bank of Ethiopia. Currently, the number of private commercial banks in Ethiopia reached nineteen includes Awash International Bank, which is the first private commercial bank.

Banks are the most leveraged industry of any economy, so stability and soundness is an important parameter in the banking system. The main goal of banks in today's financial condition is to maintain stability and make sure that they are 
resistant to outer shocks while at the same time being sensible and sound from inside. Hence, it is significant to calculate soundness across top banks in the country, spot the weaker sections of this sector, formulate appropriate policies and strategies to raise these sections and finally create an environment that leads this banking industry to converge in soundness and produce a consistently stable structure. There has been a lot of research literature highlighting these aspects and, to a great extent, showing different associations between these key macroeconomic and financial variables. This paper analyzed the various aspects of performance and soundness of the banking Industry in the country using both CAMEL approach, and econometric analysis. In order to identify the major factors that affects banks performance as identified by Basel Capital Accord, the study used econometric analysis of the Secondary Data collected from various authentic sources for a period of 14 years, from 2000 to 2013, and provides a simplistic approach to decision makers and shareholders in the judgment of the soundness and stability of banks for long periods.

\subsection{Objectives of the Study}

The overall objective of the study is to evaluate the financial performance of commercial banks and assess the relationship between capital adequacy and performance.

\subsection{Specific Objectives}

- To examine the financial position of banking sector in the country

- To explore the management efficiency of the industry

- To analyze the asset utilization capacity of banking sector

- Te determine the earning capacity of banks in the country

- To examine the relationship between capital adequacy and bank performance.

\section{Literature Review}

The financial system especially the banking sector is highly concentrated. Concentration in the market is a barrier for the presence of a well-built competition and the prevalence of excessive unutilized financial potential in the form of excess reserves and liquidity impedes efficiency of banks. The market structure for commercial banks in the economy is found highly concentrated especially in total assets and deposits towards public banks, especially in total assets and deposits towards public bank, especially the Commercial Bank of Ethiopia. Size of banks measured by total assets and branch network and age are found negatively related with efficiency while capital is found to be positively affecting efficiency of banks. The traditional method of approaching the efficiency measurement issue of financial firms, such as banks is the financial ratio analysis.

A Performance measure is the specific quantitative representation of a capacity, process, or outcome deemed relevant to the assessment of performance. Now days, the most commonly used approach of evaluating the overall performance of financial institutions as shown/proven in different literatures is CAMEL rating system. Hence, the researcher tried to assess the financial performance of financial institutions, particularly the banking sector, using the both descriptive (CAMEL) and inferential statistics. Different researchers used CAMEL model to evaluate the financial performance of different banks. Vivid V. Tuna (2013) used a CAMEL model for making a comparative analysis between two banks in Indonesia to determine level of health of the banks. At the end of its study he concluded that he didn't get any significant difference between the two banks in their financial soundness. On the other hand Prasad, K.V.N. and Ravinder, G.(2012) has used camel model to analyze the financial performance of nationalized banks in India. In their study they analyzed the camel ratios of 20 bank and they ranked these banks based on their performance. Reddy (2012) had conducted a research to examine the Relative performance of commercial banks in India by applying camel model. In his study Reddy took 26 public, 19 domestic private sector and 16 foreign banks. After analysis, Reddy concluded that public sector banks have significantly improved indicating positive impact of the reforms in liberalizing interest rates, rationalizing directed credit and Investments and increasing competition during the study period.

CAMEL is a rating system generally used by the government policy circle, regulating bodies of commercial banks, that is, central banks and non-governmental policy research centers for the purpose of assessing the soundness of financial institutions. In this connection, Piyu rightly observed: "Currently, financial ratios are often used to measure the overall soundness of a bank and the quality of bank management. Thus, bank regulators may use financial ratios to help evaluate a bank's performance as part of CAMEL rating system" (Piyu, 1992). The criteria for the performance of all the financial institutions under CAMEL Ratings include capital adequacy, asset's quality, management standard, earnings and liquidity maintenance (CAMEL). In some countries it is called CAMELS; because in addition to above mentioned five areas, system and sensibility is also considered as a barometer to judge a financial institutions' success or failure.

\section{Capital Adequacy Ratio}

This new awareness that the risks facing MFIs are similar and sometimes connected to those of mainstream banks may in fact turn out to be a boon. It gives MFIs the opportunity to review and improve their capital planning and risk management in order to improve performance and the likelihood of surviving future shocks. According to the Basel Committee on Banking Supervision, an international forum for setting guidelines and standards for banking supervisory practices, "a bank's ability to withstand uncertain market conditions is bolstered by maintaining a strong capital position that accounts for potential changes in the bank's strategy and volatility in market conditions over time (BCBS, 2009). 
The revisions to the SEEP Framework are currently in discussion phase, but one notable addition is the Capital Adequacy Ratio (CAR). CAR is an indicator of an MFI's ability to meet its obligations and absorb unexpected losses (Ibid). It measures the amount of capital relative to risk-weighted assets that a financial institutions should have, in accordance with Basel-II recommendations.

$$
\begin{aligned}
& \text { Capital Adequacy } \\
& \text { Ratio }(\text { CAR })=\text { Risk Weighted Assets }
\end{aligned}
$$

Basel-II was issued in 2004 by the Basel Committee to establish a comprehensive risk framework for determining capital adequacy. The first part of the Basel-II framework, known as "Pillar 1," defined a multi-tier capital structure made up of Tier 1, or core equity capital; and Tier2, or supplementary capital such as general reserves (provisioning against unknown as opposed to known losses) and subordinated term debt. Basel II also stipulated that the total capital ratio should be no lower than $8 \%$ (BCBS, 2006).

According to BCBS (July 2009), Recent publications of the Basel Committee have reemphasized that "Pillar1capital requirements represent minimum standards. An appropriate level of capital under Pillar 2 should exceed the minimum Pillar 1 requirements so that all risks of a bank...are adequately covered..." Where Pillar 1 set the two-tiered capital structure and minimum capitalization levels, Pillar 2 of the Basel II framework requires banks to have an internal capital adequacy assessment process (ICAAP) to determine their capital needs in light of their risk profile. That is, banks should have a comprehensive risk management system to identify, monitor, and manage all risks that they face and set their capitalization levels accordingly.

\section{Research Methodology}

To analyze the financial performance of banking industry in Ethiopia, the quantitative approach was used. The data for the study has been collected from the regular publication of NBE for the accounting period of 2000-2013. The banks selected for the purpose of the study are Commercial Bank of Ethiopia (CBE), Awash International Bank (AIB), Dashen Bank (DB), Construction and Business Bank (CCB), Bank of Abyssinia (BOA), Wegagen Bank (WB), United Bank (UB) and Nib International Bank (NIB). In order to analyze the secondary data, both descriptive and regression were employed. The descriptive data was computed using CAMEL approach and the multiple regression analysis was estimated using generalized least square, GLS. The reason for using generalized least square estimation technique is that it will minimize or avoid the level of multicollinearity problem if there is in panel data regression.

\subsection{Methods of Sampling and Data Analysis}

To judge the financial soundness of banking sector in the country, the top eight commercial banks operating in Ethiopia were selected based on their total assets and year of establishment, before 2001. An internationally accepted simplified approach CAMEL rating parameters has been used for the descriptive part of the study.Here different categories of CAMEL ratios will be calculated for the banks and the analysis were made based on the outcome to determine the achievements of the banks in capital adequacy, asset management, management efficiency, earning quality and liquidity. Once soundness across banks were determined using the CAMEL model, inferences were drawn regarding convergence across these banks based on the regression model.The results were presented using tables for easy understanding for the readers.

\subsection{Hypothesis and Statistical Estimation}

The Basel Capital Accord is an international standard for the calculation of adequacy capital. In its analyses of 1999, the accord incorporated various variables that affect bank soundness and safety into its framework. These variable include: Owners capital, Assets quality, Total deposit, Loans and Advances, Ratio of capital to total assets, Credit exposures, Returns, Market discipline and effective supervision. The above framework was modified and expressed in functional relationship as shown below in order to fit into the analysis. Thus, multiple regressions were used for the regression analysis and inferences were drawn based on the regression analysis.

The model is given as

$$
\mathrm{ROA}_{, t}=\mathrm{f}\left(\mathrm{LA}_{\mathrm{j}, \mathrm{t}}, \mathrm{TA}_{\mathrm{j}, \mathrm{t}}, \mathrm{SF}_{\mathrm{j}, \mathrm{t}}, \mathrm{CD}_{\mathrm{j}, \mathrm{t}}\right)
$$

Where: $R O A_{j, t}=$ return on Assetof firm $j$ at time $t$.

$\mathrm{LA}=$ Loans and Advances of firm $\mathrm{j}$ at time $\mathrm{t}$.

$\mathrm{SF}=$ Shareholders Fund of firm $\mathrm{j}$ at time $\mathrm{t}$.

$\mathrm{TA}=$ Total Asset of firm $\mathrm{j}$ at time $\mathrm{t}$.

$\mathrm{CD}=$ Customer Deposit of firm $\mathrm{j}$ at time $\mathrm{t}$.

The theoretical expectation and behaviour of the parameter can be determined as the basis of the theoretical reasoning. In the above equation, Loans and advances (LA j,t), Total Assets (TA j,t), Customers' deposits (CD j,t) and shareholders' funds $(\mathrm{SF}, \mathrm{j}, \mathrm{t})$ should have positive effects on the profit after tax which is the measure of bank performance. Out of these explanatory variables, the shareholders fund, (SF) which is a measure of capital adequacy is the variable of interest. The Ordinary Least Square (OLS) techniques of multiple regressions shall be adopted to examine and determine the effect of the independent variables on the dependent variables. The OLS is adopted because it has been used in a wide range of economic relationships with fairly satisfactory result.

From equation (1) above, the following equation in linear form was generated:

$$
\begin{aligned}
& \text { PAT }_{j, t}=\beta_{o}+\beta_{1} \mathrm{LA}_{\mathrm{j}, \mathrm{t}}+\beta_{2} \mathrm{TA}_{\mathrm{j}, \mathrm{t}}+\beta_{3} \mathrm{SF}_{\mathrm{j}, \mathrm{t}}+\beta_{4} \mathrm{CD}{ }_{\mathrm{j}, \mathrm{t}}+\varepsilon \mathrm{t}(2) \\
& \text { Where: } \\
& \beta \mathrm{o},=\text { Intercept } \\
& \beta 1, \beta 2, \beta 3, \beta 4=\text { Slope coefficients } \\
& \varepsilon \mathrm{t}=\text { error term } \\
& \text { The hypothesis formulated is as follows: } \\
& \text { H0: There exist no significant relationship between capital }
\end{aligned}
$$


adequacy and bank performance.

H1: There exists significant relationship between capital adequacy and bank performance.

\section{Data \& Analysis}

\subsection{Descriptive Analysis}

CAMEL is a standardized financial rating system and short form for five measures such as Capital adequacy, Asset quality, Management effectiveness, Earnings and Liquidity to market risk. For this study, the five indicators of framework showing the soundness of the financial institution are considered to analyze the performance of banking sector in Ethiopia.

\subsubsection{Capital Adequacy}

It is a duty of a bank to have the confidence of depositors and shareholder. It shows by and large financial condition of banks and also the capability of management to assemble the want for additional capital. And therefore, the researcher used capital adequacy ratio in order to evaluate the financial condition of banking sector in the country.

The overall capital adequacy of commercial banks in Ethiopia is fairly good as shown in the appendix A. As compared to the government banks, private banks financial conditions were relatively better. Of all private commercial banks, united and Nib international banks had the heist position with the average capital adequacy ratio of almost $17 \%$ which is higher than the international standard of $8.1 \%$.

\subsubsection{Asset Quality}

The quality of assets is an important parameter to gauge the strength of a bank. The logic behind calculating the asset quality is to determine the employment of assets in investment using net income as a fraction of the bank total assets (ROA). The table summarizing the results was given in the appendix A.The ROA of all banks in the country ranges from $1.8 \%$ to $14.7 \%$ earned by $\mathrm{CCB}$ and NIB respectively. Of course the returns of the companies are almost equal except NIB that had earned a two digit. From this we can infer that, the asset quality of all banks in Ethiopia is more or less the same.

\subsubsection{Management Efficiency}

Management efficiency is a key to judge the decision making capacity of managing board, as ingredients of the CAMEL Model. The ratio is to capture the possible subjective dynamics of the effectiveness of management. The ratios to assess the management efficiency banking sector used for this study are return on equity and asset turnover. Return on the Net worth/equity shows the percentage of return on the total net worth of the bank and interpreted as the return that the owners have generated on their single birr invested. The ROE of banking sector in Ethiopia ranges from 16\% (lowest) to $82.9 \%$ (highest) which were generated by BOA and NIB respectively, it shows a good management performance through there exists a big variation among companies performance. Combined average data show NIB management team is good in the Asset rotation cycle as compared to other
Banks.

\subsubsection{Earning Quality}

The excellence of earnings determines the capability of a bank to earn consistently. It mainly determines the profitability and productivity of the bank, explains the growth and sustainability in future earnings capacity. Of the many ratios used to explain the capacity of income creation, net profit margin was used for this study.Net Profit Margin (NPM) measures the absolute value of a profit level as a percentage of net income to sales or revenues, which is a comprehensive measure of a company's profitability. As shown in the appendix A, the NPM of banking sector in Ethiopia is between $59.1 \%$ to $38.6 \%$. In a common rule of thumb, a banks NPM greater than $3 \%$ is considered as above satisfactory. Therefore, overall the profit margin of the sector is very high as shown by the analysis result with the highest return is that of NIB and followed by the $\mathrm{CBE}$ and the least one is that of $\mathrm{CCB}$.

\subsubsection{Liquidity}

Managing Liquidity in banks is an important task due to competitive stress. The proper liquidity management can be used to hedge Risk of liquidity and ensuring superior percentage of return on invested funds. The Liquidity position can be gauged by Current Asset to current liability Ratio (CR), Investment to Deposit ratio (IDR) and Cash to Deposit Ratio (CDR). Current Asset to current liability Ratio shows cash in hand and deposit with central bank with proportion of total deposit in a Bank. In general, these all ratios are used to measure a bank's ability to pay immediate its short-term obligations using the most liquid assets, such as cash. As shown in the appendix $\mathrm{A}$, the $\mathrm{CR}$ of the sector ranges from 0.59 to $1.185 \%$; IDR $5.2 \%$ to $50.9 \%$; and CDR ranges from $22.2 \%$ to $48.3 \%$. The liquidity position of NIB is better than the rest of the banks as it is indicated by the CR and CDR this implies that these banks are in a better position to meet immediate and long term financial needs with a quality investment asset.

\subsection{Econometric Analysis}

Table 4.1. Regression output.

\begin{tabular}{|c|c|c|c|c|c|c|}
\hline ROA & Coef. & $\begin{array}{l}\text { Std. } \\
\text { Err. }\end{array}$ & $\mathbf{z}$ & $\mathbf{P}>\mathbf{Z}$ & $\begin{array}{l}95 \% \\
\text { Conf. }\end{array}$ & Interval \\
\hline $\begin{array}{l}\text { Loan } \\
\text { Advance }\end{array}$ & $4.08 \mathrm{e}$ & $6.55 \mathrm{e}-1$ & 0.62 & 0.534 & $-8.77 e-1$ & $1.69 \mathrm{e}-1$ \\
\hline Total Assets & $-2.01 \mathrm{e}$ & $2.18 \mathrm{e}-1$ & -0.9 & 0.357 & $-6.27 e-1$ & $2.26 \mathrm{e}-1$ \\
\hline $\begin{array}{l}\text { Shareholders } \\
\text { Fund }\end{array}$ & $7.24 \mathrm{e}$ & $3.44 \mathrm{e}-11$ & 2.10 & 0.035 & $4.95 \mathrm{e}-12$ & $1.40 \mathrm{e}-1$ \\
\hline $\begin{array}{l}\text { Customer } \\
\text { Deposit }\end{array}$ & $-4.62 e$ & $4.05 \mathrm{e}-12$ & -1.14 & 0.254 & $-1.26 \mathrm{e}-1$ & $3.32 \mathrm{e}-1$ \\
\hline Cons & .0125 & .023839 & 0.53 & 0.59 & -.034184 & .059264 \\
\hline
\end{tabular}

Source: Stata 12.0 Output File

The correlation of all independent variable to the dependent variable is good as shown by their respective coefficient in the appendix A. The correlations among independent variables are good and it shows nonexistence of multicollinearity problem. As per the rule of thumb, correlation coefficient of 
above 0.80 or 0.90 shows severity of multicollinearity problem but in this model the maximum value is very far from the upper limit. Hence, since there is no multicollinearity problem, it is logical to this model.

As shown in the tables above, two variables, customer deposit and Total Asset, have negative relation with bank performance whereas, loan and advance and shareholders fund, have positive relation with the performance of banking sector in Ethiopia even though only shareholders fund is the significant factor that affects performance at $5 \%$. The objective of running the model was to see whether capital adequacy which is measured by the amount of shareholders fund affect the bank performance which is measured by net income divided to total assets. The conclusion is that, shareholders' fund is the main factor that determines the performance of banking industry hence, the null hypothesis is rejected. Therefore, the study inferred that, there exists positive relationship between capital adequacy and bank performance at $5 \%$ significant level, which is in line with theory. This indicates that, as the level of fund raised from the owners or stockholders increases, the level of the banks performance will also increases significantly. This may be true because of the fact that as the level of debt increases, the net return of the banks will decrease since interest is part of the operating expenses. Similarly, as the econometric finding shows, customer deposit which is part of the banks liability has a negative relation to bank's performance though insignificant. Hence, in Ethiopian banking industry, the level of owners deposit has positive and significant effect on the profitability of the banks but this doesn't mean than banks should stop financing their operation from creditors/depositors rather they should keep financing from owners as much as possible too.

\section{Conclusion}

The Growth and financial performance of banking industry is one of the most important factors of Economic development of a country. The current study has been done to find the economic soundness of banks in Ethiopia using CAMEL model during the period 2000-13.

- The main findings of the descriptive study areas follow:

- Nib International Bank is on top position in terms of capital adequacy and also the heist in terms of ROE and ROA followed by united bank.

- Earning quality of SBI and PNB are on top.

- Nib International Bank and CBE are the most efficient in managing their Liquidity.

- The overall combined performance table shows that, NIB is ranked first followed by CBB and UB bank.

- The main finding of the regression analysis is that, there is a positive relationship between capital adequacy and bank performance at 5\% significant level, which supports the theory and the past studies made in different parts of the world.

- It had been indicated by the regression analysis above that owns fund has positive and significant effect whereas the customer deposit/creditors fund has negative effect though insignificant on the overall performance of the banking industry in Ethiopia. Therefore, in order to maximize the profitable level, banking industry in Ethiopia should look for financing from owners in the form of issuing stock as much as possible instead of solely depending upon fund from creditors or depositors.

\section{Appendix A}

- Financial Ratios of Banking sector in Ethiopia using CAMEL Approach.

\begin{tabular}{|c|c|c|c|c|c|c|c|c|}
\hline Company & CBE & CCB & DB & AIB & BOA & WB & UB & NIB \\
\hline Average CAR & 0.061 & 0.088 & 0.087 & 0.116 & 0.119 & 0.134 & 0.166 & 0.167 \\
\hline Average ROA & 0.019 & 0.018 & 0.025 & 0.024 & 0.019 & 0.027 & 0.023 & 0.147 \\
\hline Average ATOR & 0.034 & 0.049 & 0.049 & 0.050 & 0.056 & 0.053 & 0.050 & 0.049 \\
\hline Average ROA & 0.316 & 0.190 & 0.282 & 0.203 & 0.160 & 0.196 & 0.167 & 0.829 \\
\hline Average NPM & 0.583 & 0.386 & 0.507 & 0.495 & 0.340 & 0.542 & 0.473 & 0.591 \\
\hline Average CDR & 0.950 & 0.691 & 0.590 & 1.096 & 1.135 & 1.152 & 1.198 & 1.185 \\
\hline Average CDR & 0.222 & 0.339 & 0.250 & 0.232 & 0.306 & 0.337 & 0.337 & 0.483 \\
\hline
\end{tabular}

Source: Researchers computed using financial report of banks, 2000-2013.

- Summarize Statistics

\begin{tabular}{lllll}
\hline Variable & Mean & Std. & Dev. & Min \\
\hline $\operatorname{lgNI}$ & $2.25 \mathrm{e}+08$ & $5.09 \mathrm{e}+08$ & -2000000 & $2.86 \mathrm{e}+09$ \\
LA & $9.18 \mathrm{e}+08$ & $4.11 \mathrm{e}+09$ & $-1.92 \mathrm{e}+10$ & $2.63 \mathrm{e}+10$ \\
TA & $1.48 \mathrm{e}+09$ & $8.67 \mathrm{e}+09$ & $-6.17 \mathrm{e}+10$ & $4.45 \mathrm{e}+10$ \\
SHF & $1.71 \mathrm{e}+08$ & $3.39 \mathrm{e}+08$ & $-4.72 \mathrm{e}+08$ & $2.71 \mathrm{e}+09$ \\
CD & $1.90 \mathrm{e}+09$ & $5.52 \mathrm{e}+09$ & $-1.99 \mathrm{e}+08$ & $3.58 \mathrm{e}+10$ \\
\hline
\end{tabular}

Source: Stata 12.0 Output File
- Correlation coefficient

\begin{tabular}{llllll}
\hline & Lg NI & $\begin{array}{l}\text { Change } \\
\text { LA }\end{array}$ & $\begin{array}{l}\text { Change } \\
\text { CD }\end{array}$ & $\begin{array}{l}\text { Change } \\
\text { TA }\end{array}$ & $\begin{array}{l}\text { Change } \\
\text { SHF }\end{array}$ \\
\hline $\lg$ NI & 1.0000 & & & & \\
LA & 0.6091 & 1.0000 & & & \\
CD & 0.9366 & 0.6310 & 1.0000 & & \\
TA & 0.1480 & 0.3018 & 0.1055 & 1.0000 & \\
SHF & 0.6570 & 0.3777 & 0.5937 & 0.1115 & 1.0000 \\
\hline
\end{tabular}

Source: Stata 12.0 Output File 


\section{References}

[1] Basel Committee on Banking Supervision (BCBS). 2009. "Enhancements to the Basel II Framework." Basel: Bank for International Settlements, July. http://www.bis.org/publ/bcbs157.htm

[2] Basel Committee on Banking Supervision (BCBS). 2009. "Strengthening the resilience of the banking sector consultative document." Basel: Bank for International Settlements, December. http://www.bis.org/ publ/bcbs164.pdf

[3] Basel Committee on Banking Supervision (BCBS). 2006. "International Convergence of Capital Measurement and Capital Standards.” Basel: Bank for International Settlements, June. http://www.bis.org/publ/bcbs128.htm

[4] Gupta, P.K. (2008), A CAMEL Model Analysis of Private Sector Banks in India. Journal of Gyan Management, 2(1), 3-8.

[5] Piyu Yue, 1992, in Federal Reserve Bank of St. Louis Review, January/February 1992 Vol.74 No.1, pp. 31-45.

[6] Prasad K.V.N.G. and Ravinder, A CAMEL Model Analysis of Public and Private Sector Banks in India, Journal of Banking Financial Services and Insurance Research, 1(5) (2012).

[7] Reddy (2012), Evaluating Performance of Regional Rural Banks: An Application of CAMEL Model. Journal of Arts, Science \& Commerce, 2(4), 61-67.

[8] SEEP Network Financial Services Working Group. 2009. "Update of Key Ratios to the SEEP Framework: Draft for Review - July 2, 2009." Washington, D.C.: The SEEP Network. http://www.seepnetwork.org/Resources/SEEP\%20Frame $\% 20$ Update\%20-Draft\%20for\%20Review\%207-2-09\%20v2.pdf

[9] Vivid V. Tuna, 2013, Comparison Analysis Of Camel Ratio Between Bank Mandiri And Bank Negara Indonesia Period 2008-2012, Home Vol 1, No 4 (2013).

[10] www.nbe.gov.et. 